\title{
ANALISIS DAYA SAING USAHATANI BAWANG MERAH DI KABUPATEN BIMA
}

\section{ANALYSIS OF COMPETITIVE SHALLOTS FARMING IN BIMA REGENCY}

\author{
Nuratina Putri ${ }^{1 *}$, Efendy $^{2}$ dan Tajidan ${ }^{2}$ \\ ${ }^{1}$ Program Studi Agribisnis Fakultas Pertanian Universitas Mataram, Mataram, Indonesia \\ ${ }^{2}$ Program Studi Agribisnis Fakultas Pertanian Universitas Mataram, Mataram, Indonesia \\ *Email Penulis korespondensi: nuratinaputri9064@gmail.com
}

\begin{abstract}
Abstrak
Penelitian ini bertujuan untuk menganalisis tingkat profitibilitas finansial usahatani bawang merah dan menganalisis daya saing bawang merah di Kabupaten Bima. Metode yang digunakan adalah metode deskriptif, sedangkan pengumpulan data dilakukan dengan teknik survei. Unit analisis yang dianalisis dalam penelitian ini adalah Daya saing Bawang Merah di Kabupaten Bima. Penentuan daerah sampel dilakukan secara purposive sampling yang terdiri dari dkecamatan Woha, Kecamatan Sape dan Kecamatan Lambu. Sedangkan penentuan responden dilakukan secara Accidental Sampling yaitu sebanyak 50 responden. Jenis data yang digunakan adalah data primer dan data sekunder. Analisis data menggunakan Analisis pendapatan dan Analisis daya saing menggunakan table police analysis Matrix (PAM). Berdasarkan hasil penelitian dapat disimpulkan: (1) Usahatani Bawang Merah di Kabupaten Bima memiliki keuntungan Privat sebesar Rp 21.217.584,69 dan keuntungan sosial sebesar Rp 50.686.866,84 yang artinya usahatani bawang merah di daerah penelitian layak untuk dikembangkan karena memiliki keuntungan kompetitif dan keuntungan komparatif.;(2) Komoditas Bawang Merah di Kabupaten Bima memiliki daya saing karena memiliki keunggulan kompetitif maupun komparatif. Hal ini dapat dilihat dari nilai PCR 0,61 dan DRCR 0,46 dimana nilai masing-masing $<1$ sehingga usahatani bawang merah ini layak untuk dikembangkan.; (3) Kebijakan pemerintah pada harga input-output terhadap usahatani Bawang Merah berdampak negatif bagi penerimaan petani pada harga privat output. Berdasarkan Nilai Transfer Bersih yang negatif dan nilai NPCO yang diperoleh sebesar 0,78 yang kurang dari $<1$, namun kebijakan tersebut berdampak positif bagi petani pada harga privat input tradable berdasarkan NPCI yang diperoleh sebesar 0,94 yang berarti $<1$ memberikan arti bahwa terdapat subsidi pupuk dan obat-obatan yang membantu petani dalam mengurangi biaya input produksi.
\end{abstract}

Kata kunci : daya saing, usahatani bawang merah, PAM

\begin{abstract}
This study aims to Analyze the level of financial profitability of Shallots and, Analyze the competitiveness of Shallots in Bima Regency.The method used is descriptive method, while data collection is done by survey techniques. The unit of analysis analyzed in this study is the Red Onion Competitiveness in Bima Regency. The determination of the sample area was carried out by purposive sampling consisting of subdistricts of Woha, Sape District and Lambu District. While the determination of respondents is done by accidental sampling, as many as 50 respondents. The type of data used is primary data and secondary data. Data analysis using income analysis and competitiveness analysis using the police analysis Matrix (PAM) table. Based on the research results it can be concluded:Shallot Farming in Bima Regency has a Private profit of $R p$ 21,217,584.69 and social profit of $R p$ 50,686,866.84 which means that onion farming in the study area is feasible to be developed because it has a competitive advantage and comparative advantage, Shallot Commodities in Bima Regency are competitive because they have competitive or comparative advantages. This can be seen from the PCR value of 0.61 and DRCR 0.46 where the value of each $<1$ so that the onion farming is feasible to be developed, Government policies on input-output prices on Shallot farming negatively impact farmers' acceptance of the private price of output. Based on a negative Net Transfer Value and an NPCO value obtained of 0.78 which is less than $<1$, however the policy has a positive impact on farmers on tradable input private prices based on an NPCI obtained of 0.94 which means $<1$ means that there is a subsidy fertilizers and medicines that help farmers in reducing the costs of production inputs.
\end{abstract}

keywords: competitiveness, Shallots farming, PAM 


\section{PENDAHULUAN}

Pengembangan usahatani bawang merah di Propinsi Nusa Tenggara Barat dimulai sejak jaman dahulu kala dan sangat terkenal di seluruh Nusantara. Salah satu daerah sentra produksi bawang merah di Nusa Tenggara Barat adalah Kabupaten Bima. Potensial areal untuk pengembangan bawang merah di Kabupaten Bima cukup besar dengan prospek pemasaran hasil yang cukup menjanjikan. Pada tahun 2002 Kabupaten Bima mempunyai variates Bima (La Keta Monca Rombo Ro'o) telah dilepaskan secara nasional di Jakarta dan merupakan salah satu komoditi unggulan daera yang memiliki prospek yang cukup bagus serta permintaan pasar terhadap komoditi unggulan daerah yang memiliki prospek yang cukup bagus serta permintaan pasar terhadap komoditi tersebut yang cenderung meningkat. Di samping itu pada tahun 2009 produksi bawang merah di Kabupaten Bima mencapai 91.992 ton dari luas areal tanam $7.539 \mathrm{Ha}$ atau 7.124 Ha luas panen dengan produktivitas 129,13 kuintal (12,913 ton) dan sekitar 68.994 ton (72\%) di pasarkan ke luar daerah (Anonymous, 2009).

Permintaan akan komoditi bawang merah pada akhir-akhir ini cenderung meningkat, untuk mengantisipasi permintaan tersebut Kabupaten Bima di samping mengembangkan varietas lokal Bima juga varitas Super Philip, Namun peluang inipun belum dapat dipenuhi mengingat luas tanam bawang baru mencapai $54 \%$ dari potensi lahan pengembangan bawang merah sekitar 13.663 Ha. Di Kabupaten Bima Bawang merah merupakan salah satu sentra produksi bawang merah di Provinsi Nusa Tenggara Barat (NTB) yang produksinya terus meningkat dari tahun ke tahun. Hal ini tampak dari peningkaan produksi yang cukup tinggi dari 75.992 ton dengan luas panen 6.012 ha pada tahun 2009 menjadi 80.904 ton dengan luas panen sebesar 6.709 pada tahun 2014 . Peningkatan tersebut selain disebabkan karena perluasan areal juga disebabkan terjadinya peningkatan produkvitas (BPS NTB, 2014).

Sentra produksi bawang merah di Kabupaten Bima terdapat di Kecamatan Sape, Lambu, Woha, Belo, Monta dan Wera. Dari Kecamatan tersebut adalah ada tiga kecamatan yang akan menjadi daerah penelitian yaitu Kecamatan Sape, Lambu dan Woha. Tujuan Penelitian ini yaitu untuk mengetahui tingkat profitibilitas finansial Usahatani Bawang merah dan menganalisis Daya Saing Bawang Merah di Kabupaten Bima

\section{METODE PENELITIAN}

Metode yang digunakan dalam penelitian ini adalah metode deskriptif yaitu metode yang bertujuan pada pemecahan masalah yang ada dengan mengumpulkan data, menyusun, menganalisa, menginterpretasikan dan akhirnya menarik kesimpulan. Penentuan Lokasi Sampel Penelitian ini dilakukan di Kabupaten Bima terdiri dari 18 Kecamatan, selanjutnya ditetapkan tiga Kecamatan sebagai daerah sampel penelitian yaitu Kecamatan Sape , Kecamatan Lambu dan Kecamatan Woha, atas pertimbangan memiliki luas lahan dan produksi lebih luas atau lebih banyak dari kecamatan lain maka Penentuan daerah sampel ditentukan secara sengaja "Purposive Sampling" Jumlah petani sampel yang digunakan dalam penelitian ini sebanyak 50 responden dari 393 populasi petani bawang merah di Kabupaten Bima. Pemilihan responden pada setiap kecamatan dilakukan secara "Accidental Sampiling". Teknik Pengumpulan data dilakukan dengan menggunakan teknik survei atau wawancara dengan berpedoman pada daftar pertanyaan yang disisipkan sebelum berupa quesener (Sugiyono, 2015). 
Analisis Data yang digunakan adalah analisis pendapatan dan analysis daya saing yang berkaitan dengan penelitian.

\section{Analisis Pendapatan}

Penerimaan Usahatani adalah perkalian antara produksi yang diperoleh dengan harga jual (Rahim dan Hustuti,2007). Secara matematis dirumuskan sebagai berikut :

$$
\mathrm{TR}=\mathrm{Y} \text {. Py }
$$

Keterangan :

TR =total penerimaan

$\mathrm{Y} \quad=$ Produksi yang diperoleh dari suatu usahatani

Py $=$ Harga Produksi

Pendapatan merupakan selisih penerimaan dengan semua biaya produksi, Pendapatan meliputi pendapatan kotor (penerimaan total) dan pendapatan bersih. Pendapatan kotor adalah nilai produksi komoditas pertanian secara keseluruhan sebelum dikurangi biaya produksi (Rahim dan Hastuti Dwi R. D,2007).

Pendapatan dapat dirumuskan sebagai berikut :

Keterangan :

$$
\begin{aligned}
& \pi=T R-T C \\
& \pi=y . P y-\left\{\left(\sum \mathrm{Xi} . \text { Pxi }\right)-\mathrm{BTT}\right)
\end{aligned}
$$

$\begin{array}{ll}\Pi & =\text { Keuntungan/ pendapatan (Rp) } \\ \text { TR } & =\text { Total penerimaan (Rp) } \\ \text { TC } & =\text { Jumlah produksi (satuan) } \\ \text { Py } & =\text { Harga satuan produksi (Rp) } \\ \text { X } & =\text { Faktor Produksi (Satuan) } \\ \text { Px } & =\text { Harga factor Produksi (Rp/satuan) } \\ \mathrm{N} & =\text { Banyaknya input yang dipakai } \\ \text { BTT } & =\text { Biaya tetap total (Rp) }\end{array}$

\section{Analisis Daya Saing}

a. Penentuan Harga Bayangan (Sosial)

Penentuan harga bayangan output (sosial) yang digunakan adalah harga ratarata ekspor di konversi dalam nilai tukar US\$ bayangan atau shadow Exchange Rate (SER). Harga ekspor merupakan harga free on board (f.o.b) yaitu harga di pelabuhan, sedangkan penentuan harga bayangan input dalam menggunakan faktor konversi ( Suprapto, 1999)

Perhitungan SER dilakukan dengan menggunakan rumus :

$$
\begin{aligned}
& \mathrm{SER}=\frac{O E R}{S C F} \\
& \mathrm{SCF}==\frac{M+X}{(M+T m)+(X-T X)}
\end{aligned}
$$

Keterangan :

SER = shadow Exchange Rate atau nilai tukar bayangan

OER =Official Exchange Rate atau nilai tukar resmi mata uang yang berlaku (Rp)

$\mathrm{SCF} \quad=$ Standard Conertion Factor atau faktor konersi baku

$\mathrm{M} \quad=$ nilai impor $(\mathrm{Rp})$

$\mathrm{Tm} \quad=$ Pajak impor $(\mathrm{Rp})$

$\mathrm{X} \quad=$ nilai ekspor $(\mathrm{Rp})$

$\mathrm{Tx} \quad=$ pajak ekspor $(\mathrm{Rp})$ 
Harga bayangan bawang merah menggunakan data harga paritas (border price), yaitu harga cost, insurance, and freight (c.i.f) untuk produk yang dapat di ekspor (Kadariah, 2001).

Tabel 1. Penerimaan harga paritas ekspor output

\begin{tabular}{cll}
\hline NoUraian & \multicolumn{2}{c}{ Rincian } \\
\hline 1 & Harga FOB ( US\$/ton) & $\mathrm{a}$ \\
2 & Nilai tukar (Rp/US\$) & $\mathrm{X}$ \\
3 & FOB dalam mata uang domestik (Rp/ton) & $\mathrm{b}=\mathrm{a} . \mathrm{X}$ \\
4 & Faktor Konvversi & $\mathrm{Y}$ \\
5 & FOB dalam mata uang domestik (Rp/kg) & $\mathrm{c}=\mathrm{b} / \mathrm{Y}$ \\
6 & Transportasi dan handling ke pasar pedagang besar & $\mathrm{d}$ \\
7 & Harga paritas impor di pedagang besar $(\mathrm{Rp} / \mathrm{kg})$ & $\mathrm{e}=\mathrm{c}+\mathrm{d}$ \\
8 & Distrubusi ke tingkat petani $(\mathrm{Rp} / \mathrm{kg})$ & $\mathrm{f}$ \\
9 & Harga paritas impor di tingkat petani & $\mathrm{g}=\mathrm{e}+\mathrm{f}$ \\
\hline Sumber : Monke dan Pearson 2005 &
\end{tabular}

Input tradeable pada usahatani bawang merah meliputi pupuk, benih padi, dan pestisida. Penghitungan harga paritas input tradeable menggunakan data harga CIF, jika input tradeable merupakan barang impor.

Tabel 2. Penentuan harga paritas impor input

\begin{tabular}{lll}
\hline \multicolumn{2}{c}{ No Uraian } & \multicolumn{1}{c}{ Rincian } \\
Harga CIF (US\$/kg) & $\mathrm{A}$ \\
2 & Nilai tukar (Rp/ US\$) & $\mathrm{X}$ \\
3 & CIF dalam mata uang domestik $(\mathrm{Rp} / \mathrm{Kg})$ & $\mathrm{b}=\mathrm{a} . \mathrm{X}$ \\
4 & Bongkar/muat, gudang, susut & $\mathrm{c}$ \\
5 & Biaya transportasi ke provinsi $(\mathrm{Rp} / \mathrm{Kg})$ & $\mathrm{d}$ \\
6 & Nilai sebelum pengolahan $(\mathrm{Rp} / \mathrm{Kg})$ & $\mathrm{e}=\mathrm{b}+\mathrm{c}+\mathrm{d}$ \\
7 & Faktor Konversi proses $(\%)$ & $\mathrm{Y}$ \\
8 & Harga Paritas ekspor di pedagang besar $(\mathrm{Rp} / \mathrm{Kg})$ & $\mathrm{f}=\mathrm{e} . \mathrm{Y}$ \\
9 & Distrubusi ke tingkat petani $(\mathrm{Rp} / \mathrm{Kg})$ & $\mathrm{g}$ \\
10 Harga paritas impor di tingkat petani $(\mathrm{Rp} / \mathrm{Kg})$ & $\mathrm{h}=\mathrm{f}+\mathrm{g}$ \\
\hline
\end{tabular}

Sumber : Monke dan Pearson, 2005

b. Anaisis Daya Saing Menggunakan Tabel PAM

Analisis daya saing dilakukan dengan menggunakan tbel analisis PAM (Policy Analysis Matrix) dan indikator yang digunakan terbatas hanya pada PCR dan DRCR. Perhitungan model (PAM) secara tabulasi dapat diformulasikan sebagai berikut :

Tabel 3. Policy Analysis Matrix (PAM)

\begin{tabular}{lcccc} 
& \multicolumn{4}{c}{ Biaya } \\
\hline Deskripsi & Revenue & \multicolumn{4}{c}{ Profit } \\
\hline Harga privat & $\mathrm{A}$ & Input & Tradeable & Tradeable \\
Harga Sosial & $\mathrm{E}$ & $\mathrm{B}$ & $\mathrm{C}$ & $\mathrm{D}$ \\
Pengaruh & $\mathrm{I}$ & $\mathrm{F}$ & $\mathrm{G}$ & $\mathrm{H}$ \\
divergensi & & $\mathrm{J}$ & $\mathrm{K}$ & $\mathrm{L}$ \\
\hline
\end{tabular}

Sumber : :Monke dan Pearson (1976), dalam Soetriono (2002) 


\section{HASIL DAN PEMBAHASAN}

\section{Karakteristik Petani Responden}

Karakteristik petani responden dalam penelitian ini dilihat dari umur, tingkat pendidikan, jumlah anggota keluarga, luas lahan dan pengalaman berusahatani kedelai. Karakteristik tersebut dianggap penting karena akan mempengaruhi pendapatan petani pada usahatani bawang merah di lokasi penelitian. Umur petani responden petani bawang merah paling banyak terdapat pada kisaran umur 15-64 tahun yaitu sebanyak 50 orang atau $100 \%$, dan sebagian besar responden masih tergolong usia produktif, artinya baik secara fisik maupun mental memiliki kemampuan dalam berusahatani. Hal ini sesuai dengan kisaran usia produktif yaitu antara 15-64 tahun dianggap mampu bekerja. Pengusaha yang masih tergolong usia produktif biasanya makin respon atau makin tanggap terhadap suatu masalah (Simanjuntak, 1985).

Rata-rata tingkat pendidikan petani responden bawang merah di kabupaten bima menunjukan yang tamat SD sebanyak 9 orang (18\%) tamat SMP sebanyak 9 orang $(18 \%)$, tamat SMA sebanyak 25 orang $(50 \%)$ dan tamat perguruan tinggi sebanyak 7 orang (14\%). Tingkat pendidikan petani sangat berpengaruh dalam penyerapan tekhnologi dan informasi dalam pelaksaanaan usahataninya.

Pengalaman berusahatani responden secara umum terbanyak pada kissaran 512 tahun sebanyak 24 orang (48\%) dan 13-20 tahun sebanyak 11 orang (22\%) dan 2130 tahun sebanyak 9 orang $(18 \%)$, dan $\geq 29$ sebanyak 6 orang $(12 \%)$. Hal ini menunjukan responden cukup berpengalaman dalam berusahatani bawang merah, pengalaman ini merupakan modal dasar dalam menerima inovasi untuk meningkatkan pengalaman produkvitas tenaga kerja. jumlah tanggungan usahatani bawang merah berkisaran 0-2 adalah sebanyak 10 orang (20\%), sedangkan jumlah tanggungan 3-4 orang adalah sebanyak $32(64 \%)$, pada kisaran $\geq 5$ orang adalah sebanyak 8 orang (16\%). Jumlah anggota keluarga akan berpengaruh terhadap perekonomian keluarga, semakin banyak jumlah anggota keluarga maka akan semakin meningkat pula kebutuhan keluarga, hal ini akan membuat biaya hidup meningkat.

Luas lahan yang dimiliki oleh petani responden bawang merah di kabupaten Bima sangat mempengaruhi jumlah produksi yang diperoleh, sebagian besar petani responden bawang merah memiliki luas lahan berkisar antara 0,08-0,35 Ha sebanyak 26 orang (52\%), petani yang memiliki luas lahan $0,36-0,60$ Ha sebanyak 18 orang $(36 \%)$, sedangkan petani yang memiliki luas lahan $\geq 0,61$ Ha sebanyak 6 orang (12\%). dan ratarata luas lahan responden $0.45 \mathrm{LLG}$ atau $1.00 \mathrm{Ha}$. status lahan petani responden di Kabupaten Bima rata-rata 50 orang milik sendiri dengan persentase $100 \%$. Dan tidak ditemukan petani dengan bagi hasil ataupun digadai.

\section{Analisis Biaya dan Pendapatan Usahatani Bawang Merah}

Adapun biaya pada penelitian ini meliputi biaya tetap dan biaya variabel. Biaya tetap adalah biaya yang besar kecilnya tidak dipengaruhi oleh besar kecilnya volume produksi. Biaya tetap meliputi biaya pajak lahan, dan biaya penyusutan alat. Secara rinci biaya-biaya tersebut disajikan dalam tabel 4 
Tabel 4. Biaya Tetap Usahatani Bawang Merah di Kabupaten Bima Tahun 2019.

\begin{tabular}{llrr}
\hline \multirow{2}{*}{ No. } & Jenis Biaya & \multicolumn{2}{c}{ Nilai (Rp) } \\
\cline { 3 - 4 } & Tetap & \multicolumn{1}{c}{ Per Ha $(1,00)$} \\
\hline 1. & Pajak Tanah & $17.646,62$ & $39.337,09$ \\
2. & Penyusutan Alat: & $5.360,00$ & $11.948,28$ \\
& Cangkul & 28.000 & $62.416,41$ \\
& Sprayer & $4.688,00$ & $10.449,18$ \\
Ember & $42.188,00$ & $94.042,58$ \\
Tarpal & 2.000 & $4.458,31$ \\
& Parang & 400.00 & 891,66 \\
& Penyungkil & $60.156,00$ & $134.097,75$ \\
& Mesin air & $11.719,00$ & $26.122,94$ \\
\hline Timbangan Air & $154.510,00$ & $344.427,11$ \\
\hline & Sub Total & $172.156,62$ & $383.765,20$ \\
\hline
\end{tabular}

Sumber : Data Primer Diolah 2019

Tabel 4 menunjukkan bahwa biaya tetap terbesar dikeluarkan pada biaya penyusutan alat yaitu sebesar Rp.154.510,00 per luas lahan garapan, dan Rp. 344.427,11 per hektar dari total biaya tetap. Besarnya biaya penyusutan tersebut disebabkan karena jumlah alat yang digunakan relatif banyak. Kemudian pada biaya penyusutan alat tersebut, biaya terbesar yaitu pada pembelian mesin air, karena mesin air merupakan alat dengan biaya beli termahal dibandingkan dengan alat-alat yang lain.

Tabel 5. Rata-rata Biaya Variabel yang dibutukan Petani Responden di Kabupaten Bima 2019.

\begin{tabular}{|c|c|c|c|c|c|}
\hline \multirow{2}{*}{ No. } & \multirow{2}{*}{ Jenis Biaya } & \multicolumn{2}{|c|}{ Per LLG $(0,45)$} & \multicolumn{2}{|r|}{ Per Ha $(1,00)$} \\
\hline & & Fisik & Nilai (Rp) & Fisik & Nilai (Rp) \\
\hline 1. & Benih $(\mathrm{Kg})$ & 571,60 & $8.574 .000,00$ & $1.274,19$ & $19.112 .795,36$ \\
\hline \multirow[t]{6}{*}{2.} & Pupuk & - & - & - & \\
\hline & Urea $(\mathrm{Kg})$ & 261,00 & $652.500,00$ & 581,04 & $1.454 .525,19$ \\
\hline & SP36 (Kg) & 59,00 & $135.700,00$ & 131,52 & $302.496,66$ \\
\hline & $\mathrm{KCL}(\mathrm{Kg})$ & 76,80 & $614.400,00$ & 171,20 & $1.369 .594,29$ \\
\hline & NPK (Kg) & 185,40 & $426.420,00$ & 413,29 & $950.557,29$ \\
\hline & Jumlah & & $10.403,020,00$ & & $23.189 .968,79$ \\
\hline \multirow[t]{6}{*}{3.} & $\begin{array}{l}\text { Pestisida/obat- } \\
\text { obatan }\end{array}$ & - & - & - & - \\
\hline & Antracol (Kg) & 1,12 & $134.400,00$ & 2,50 & $299.598,75$ \\
\hline & Lanate $(\mathrm{Kg})$ & 1,30 & $78.000,00$ & 2,90 & $173.874,28$ \\
\hline & Tripas (Lt) & 3,04 & $790.400,00$ & 6,78 & $1.761 .925,99$ \\
\hline & Seprint (Lt) & 2,66 & $266.000,00$ & 5,93 & $592.955,86$ \\
\hline & Jumlah & & 1.268 .800 .00 & & $2.828 .354,88$ \\
\hline 4 & $\begin{array}{l}\text { Biaya Tenaga } \\
\text { Kerja }\end{array}$ & & $5.780 .000,00$ & & $12.882 .302,51$ \\
\hline \multirow[t]{2}{*}{5} & Biaya Lainnya & & $100.890,00$ & & $224.899,00$ \\
\hline & Biaya & & $17.552 .710,00$ & & $39.125 .525,18$ \\
\hline
\end{tabular}

Sumber : Data Primer Diolah 2019 
Biaya variabel yang paling besar adalah biaya pembeilan benih bawang merah. Besarnya biaya pembelian benih disebabkan karena harga benih tergolong tinggi dan jumlah yang dibutuhkan untuk proses penanaman banyak. Selain itu biaya pestisida/obat-obatan juga terbilang cukup tinggi yaitu Rp 1.268.800,00 perLLG atau Rp 12.828.354,88 perHa dari total biaya sarana produksi, karena petani banyak membeli obat-obatan untuk membantu pertumbuhan bawang merah yang rentan terhadap serangan hama dan penyakit.

\section{Produksi, Penerimaan, dan Pendapatan Usahatani Bawang Merah.}

Produksi yang dimaksud ialah hasil dari usahatani bawang merah petani responden di Kabupaten Bima dalam satu kali proses produksi atau satu kali musim tanam. Kemudian penerimaan yaitu volume penjualan dikalikan dengan harga jual sedangkan pendapatan bersih usahatani bawang merah diperoleh dari total penerimaan dikurangi total biaya produksi. Berdasarkan hasil penelitian, secara rinci akan ditunjukan pada tabel 6 berikut.

Tabel 6. Produksi, Penerimaan, dan Pendapatan pada Usahatani Bawang Merah diKabupaten Bima Tahun 2019

\begin{tabular}{llrr}
\hline No. & \multicolumn{1}{c}{ Uraian } & Per LLG $(0,45)$ & \multicolumn{1}{c}{ Per Ha $(1,00)$} \\
\hline 1. & Produksi (Ton) & $5.754,00$ & $12.826,57$ \\
3. & Harga (Rp/Kg) & 14.000 & 14.000 \\
4. & Nila Produksi(Rp) & $80.556,000$ & $179.571,980$ \\
5. & Biaya Produksi (Rp) & $17.724 .866,62$ & $39.681 .244,36$ \\
6. & Pendapatan (Rp) & $62.831 .133,38$ & $139.890 .735,64$ \\
\hline
\end{tabular}

Sumber : Data Primer Diolah 2019

Tabel 6. menunjukkan bahwa jumlah produksi bawang merah sebesar 5.754 ton per luas lahan garapan atau 12.826,57 ton per hektar. Harga jual bawang merah pada daerah penelitian rata-rata sebesar Rp. 14.000 per kilogram sehingga jumlah penerimaan usahatani sebesar $\mathrm{Rp} 80.556,000$ per luas lahan garapan atau Rp 179.571,980 per hektar. Kemudian dari hasil tersebut maka pendapatan bersih petani responden pada usahatani bawang merah di Kabupaten Bima yaitu sebesar Rp. 62.831.133,38 per luas lahan garapan dan atau Rp. 139.890.735,64 per hektar. Dari hasil tersebut menunjukan bahwa pendapatan yang diperoleh petani bernilai positif dan besar sehingga usaha tersebut layak untuk diusahakan.

\section{Analisis Keuntungan Privat dan Sosial}

Sebelum melakukan analisis daya saing, terlebih dahulu dilakukan analisis usahatani kemudian dilanjutkan dengan membandingkan harga aktual dan harga sosialnya agar diketahui apakah usahatani tersebut memiliki nilai daya saing atau tidak. Pendekatan yang digunakan untuk mengukur daya saing suatu komoditas dapat dilihat dari keunggulan kompetitif dan komparatif. Adapun tabel matriks analisis kebijakan usahatani Bawang Merah di Kabupaten Bima adalah :

Tabel 7. Matriks Analisis Kebijakan Usahatani Bawang Merah di Kabupaten Bima Tahun 2019

\begin{tabular}{ccccc}
\hline & & \multicolumn{2}{c}{ Biaya Input } & \\
\cline { 3 - 4 } Uraian & Penerimaan & Tradable & Non Tradable & Keuntungan \\
\hline Harga Privat & 80.556 .000 & 26.018 .323 .67 & 33.320 .091 .64 & $21.217 .584,69$ \\
& $\mathrm{~A}$ & $\mathrm{~B}$ & $\mathrm{C}$ & $\mathrm{D}$ \\
Harga Sosial & 103.572 .000 & $27.722 .344,18$ & $25.162 .768,98$ & $50.686 .886,84$ \\
& $\mathrm{E}$ & $\mathrm{F}$ & $\mathrm{G}$ & $\mathrm{H}$ \\
Divergensi & $(23.016 .000)$ & $(1.704 .020,51)$ & $8.157 .322,98$ & $(29.469 .302,15)$ \\
& $\mathrm{I}$ & $\mathrm{J}$ & $\mathrm{K}$ & $\mathrm{L}$ \\
\hline
\end{tabular}


Sumber : Data primer diolah 2019

Keterangan :

Keuntungan privat $(\mathrm{D})=\mathrm{A}-(\mathrm{B}+\mathrm{C})$

Transfer input tradable $(\mathrm{J})=\mathrm{B}-\mathrm{F}$

Keuntungan social $(\mathrm{H})=\mathrm{E}-(\mathrm{F}+\mathrm{G})$

Transfer input non radable $(\mathrm{K})=\mathrm{C}-\mathrm{G}$

Rasio biaya privat $(\mathrm{PCR})=\mathrm{C} /(\mathrm{A}-\mathrm{B})$

Transfer output $(\mathrm{I})=\mathrm{A}-\mathrm{E}$

Transfer Bersih $(\mathrm{L})=\mathrm{D}-\mathrm{H}$

Koefisien Keuntungan $(\mathrm{PC})=\mathrm{D} / \mathrm{H}$

Koefisien proteksi output nominal $(\mathrm{NPCO})=\mathrm{A} / \mathrm{E}$

Koefisien proteksi input nominal $(\mathrm{NPCI})=\mathrm{B} / \mathrm{F}$

Koefisien proteksi efektif $($ EPC $)=(A-B) /(E-F)$

Rasio subsidi bagi produsen $(\mathrm{SRP})=\mathrm{L} / \mathrm{E}$

Rasio biaya sumber daya domestic $(\mathrm{DRCR})=\mathrm{G} /(\mathrm{E}-\mathrm{F})$

\section{Analisis Keunggulan Kompetitif dan Komparatif}

Kondisi keunggulan kompetitif bawang merah di daerah penelitian dan dapat melihat alokasi sumberdaya untuk mencapai efisiensi secara finansial dalam usahatani bawang merah. Efisiensi secara finansial diukur dengan menggunakan indicator PCR. PCR merupakan perhitungan dengan melihat rasio antara biaya Input Non Tradable dengan penerimaan dan Biaya Input Tradable.

Nilai PCR menunjukan kemampuan suatu system komoditas dalam membiayai faktor domestiknya pada harga privat. Semakin kecil nilai PCR maka semakin bertingkat keunggulan kompetitif dari usahatani suatu komoditas (Pearson, 2005 ). Nilai PCR untuk usaha tani bawang merah lebih kecil dari 1 yaitu 0,61 , artinya usaha tani bawang merah baik untuk diusahakan karena memiliki keunggulan kompetitif.

Sedangkan Nilai DRCR merupakan rasio antara biaya faktor domestik dengan selisih antara penerimaan dengan biaya input tradable pada harga bayangan (social) atau harga yang didalamnya tidak terdapat kebijakan pemerintah. Sedangkan nilai DRCR usahatani bawang merah di Kabupaten Bima adalah 0,46 yang artinya memiliki keunggulan komparatif.

Berdasarkan hasil analisis PCR dan DRCR pada usahatani bawang merah di atas menunjukan nilai PCR $<1$ dan DRCR $<1$. Dengan demikian usahatani bawang merah di Kabupaten Bima memiliki keunggulan kompetitif dan keunggulan komparatif yang tinggi. Hal ini menunjukan bahwa usaha tani bawang merah di daerah penelitian baik untuk dikembangkan untuk menjadi komoditas unggulan.

\section{Dampak Kebijakan Pemerintah}

Dampak kebijakan pemerintah terhadap harga input-output usahatani bawang merah diperlihatkan oleh nilai efek divergensi. Nilai efek divergensi diperoleh dari hasil tabulasi Policy Analysis Matrix ( PAM ) yang menjelaskan seberapa besar dampak kebijakan output, input dan input-output yang menyebabkan harga privat berbeda dengan harga social. Berikut ini diuraikan dampak kebijakan terhadap output, input dan input-output.

\section{a. Kebijakan Output}


Tabel 8. Indikator dampak kebijakan pemerintah terhadap output usaha tani bawang merah di Kabupaten Bima Tahun 2019

\begin{tabular}{lcc}
\hline \multicolumn{3}{c}{ Indikator dampak kebijakan output } \\
\hline No & Transfer output $(\mathrm{Rp} / \mathrm{Ha})$ & -23.061 .000 \\
\hline 1 & NPCO & 0,78
\end{tabular}

Sumber lampiran, diolah 2019

- $\quad$ Transfer Output

Transfer Output diperoleh hasil pengurangan antara penerimaan output pada harga privat (A) dengan penerimaan output pada harga social (E). Nilai Output Transfer diperoleh sebesar -23.061.000 Dengan mengacu pada kriteria Output Transfer $<0$, memberikan arti bahwa produsen menerima harga jual yang lebih rendah dari harga sosialnya, artinya petani tidak mendapatkan untung yang maksimal.

- $\quad$ Koefisien Proteksi Output Nominal

Koefisien proteksi Output Nominal (NPCO) diperoleh dari hasil pembagian antara penerimaan output pada harga privat (A) dengan penerimaan output pada harga social (E). nilai Nominal Protection Coefficient on Tradable Output diperoleh sebesar 0,78. Dengan mengacu pada kriteria Nominal Protection Coefficient on Tradable Output $<1$, memberikan arti bahwa terjadi pengurangan penerimaan petani (Pearson, 2004)

b. Kebijakan Input

Dampak kebijakan pemerintah terhadap input dapat ditinjau dari Input Transfer, Nominal Protection Coefficient on Tradable Input dan factor Transfer hal ini dapat dilihat pada tabel berikut:

Tabel 9. Indikator dampak kebijkan pemerintah terhadap input dalam Sistem Komoditas Bawang Merah di Kabupaten Bima 2019

\begin{tabular}{lcc}
\hline No & Indikator dampak kebijakan input & Nilai \\
\hline 1. & Transfer Input $(\mathrm{Rp} / \mathrm{Ha})$ & -1.704 .020 .51 \\
\hline 2. & Transfer Faktor $(\mathrm{Rp} / \mathrm{Ha})$ & $8.157 .322,98$ \\
\hline 3. & NPCI & 0,94 \\
\hline \multicolumn{2}{l}{ Sumber $:$ data } & primer diolah 2019
\end{tabular}

- Input Transfer

Input Transfer merupakan selisih antara biaya input tradable pada harga privat dengan biaya input tradable pada harga bayangan (social). Nilai Input Transfer diperoleh sebesar Rp -1.704.020,51. Dengan mengacu pada kriteria Input Transfer $<0$ menurut Pearson 2004, memberikan arti bahwa terdapat kebijakan input tradable yaitu berupa subsidi sehingga petani tidak membayar secara penuh biaya social input tradable. Subsidi yang diberikan yaitu pada pupuk Urea, SP 36, KCL, NPK. Diberlakukan subsidi pada input tersebut menyebabkan harga sosialnya lebih besar dari harga privatnya.

- Koefisien Proteksi Input Nominal

Koefisien Proteksi input nominal (NPCI) diperoleh dari hasil pembagian antara biaya privat input tradable (B) dengan antara biaya social input tradable (F). Nilai Nominal Protection Coefficient on Tradable Input diperoleh sebesar 0,94. Dengan mengacu pada kriteria Input Transfer $<1$ menurut Pearson, 2004 memberikan arti bahwa petani menerima subsidi atas input tradable, sehingga petani dapat membeli input tradable dengan harga yang lebih rendah.

- Transfer Factor 
Transfer Factor merupakan indicator dampak kebijakan pemerintah terhadap input produksi tersebut. TF merupakan selisih antara biaya input domestic yang dihitung pada harga privat dengan biaya input produksi pada harga bayangan (ekonomi). Kebijakan pemerintah untuk input domestic dilakukan dalam bentuk kebijakan subsidi (positif atau negative).

Factor Transfer $(\mathrm{K})$ diperoleh dari hasil pengurangan antara biaya privat input non tradable ( $\mathrm{C}$ ) dengan antara biaya social input non tradable (G). Nilai Factor Transfer diperoleh sebesar $\mathrm{Rp}$ 8.157.322,98. Nilai tersebut menunjukan bahwa terdapat implisit subsidi atau transfer (intensif) dari produsen input domestik karena petani bawang merah menerima harga input domestik yang lebih murah dari harga sosialnya dengan mengacu pada kriteria Factor Transfer $<0$, memberikan arti bahwa ada kebijakan pemerintah yang melindungi produsen input non tradable melalui pemberian subsidi yaitu subsidi pupuk organik, sedangkan peralatan dan lainnya tidak disubsidi.

Secara keseluruhan analisis dampak kebijakan pemerintah terhadap input produksi bawang merah mengindikasikan bahwa di bawah kebijakan pemerintah terhadap input, meningkatkan keunggulan kompetitif dan komparatif didaerah penelitian.

\section{c. Kebijakan Input-Output}

Tabel 10. Dampak kebijakan pemerintah pada input-output dapat ditinjau dari Effective Protection Cofficient, Net Transfer, Profitability Coeffisient dan Subsidy Ratio to Producer.

\begin{tabular}{lcc}
\hline No & Indikator dampak kebijakan input & \\
\hline 1 & EPC & 0,71 \\
\hline 2 & Transfer Bersih $(\mathrm{Rp} / \mathrm{Ha})$ & $-29.469 .302,15$ \\
\hline 3 & PC & 0,41 \\
\hline 4 & SRP & 0.28 \\
\hline
\end{tabular}

Sumber : Data primer diolah 2019

\section{- $\quad$ Koefisien Proteksi Efektif}

Koefisien Proteksi Efektif diperoleh dari hasil pembagian antara penerimaan pada harga privat (A) di kurangi biaya privat input tradable ( B ) dengan penerimaan pada harga social ( $E$ ) dikurangi biaya social input tradable ( $F$ ). Nilai Effective Protection Cofficient diperoleh sebesar 0,71. Dengan mengacu pada kriteria Effective Protection Cofficient $<1$ ( Pearson 2004 ), memberikan arti bahwa kebijakan pemerintah saat ini tidak berjalan secara efektif dikarenakan kebijakan pemerintah saat ini masih belum memberikan dukungan terhadap aktivitas produksi usahatani bawang merah dalam negeri. Hal ini sesuai menurut Deperindag 2007 yang mengatakan bahwa kurangnya perhatian pemerintah dalam peningkatan mutu dan kualitas bawang merah yang menyebabkan bawang merah di Indonesia kurang dapat bersaing di pasar internasional.

\section{- $\quad$ Transfer Bersih}

Transfer bersih diperoleh dari hasil pengurangan antar keuntungan pada harga privat ( D ) dengan keuntungan pada harga social ( $\mathrm{H}$ ). Nilai Net Transfer diperoleh sebesar Rp. 29.469.302,15. Dengan mengacu pada kriteria Net Transfer $<0$ memberikan arti bahwa tidak ada tambahan surplus produsen yang disebabkan oleh kebijakan pemerintah yang diterapkan pada input dan output

- Koefisien Keuntungan PC= D/H

Koefisien Keuntungan diperoleh dari hasil pembagian antara keuntungan pada harga privat ( D ) dengan keuntungan pada harga social ( $\mathrm{H}$ ). Nilai Profitability 
Coeffisiens diperoleh sebesar -0,41. Dengan mengacu pada kriteria Net Transfer $<1$, memberikan arti bahwa kebijakan pemerintah yang berlaku selama ini menyebkan produsen atau petani bawang merah mengeluarkan biaya produksi lebih besar dari biaya sosialnya untuk berproduksi.

Sehingga dapat dijelaskan bahwa kebijakan pemerintah terhadap input output usahatani bawang merah di daerah penelitian jika ditinjau dari sisi kebijakan output, kebijakan input dan kebijakan input-output maka kebijakan pemerintah berdampak negative pada penerimaan petani dari harga privat output namun berdampak positif pada petani untuk biaya private input tradable karena terdapat subsidi yang membantu petani dalam mengurangi biaya input produksi. Hal ini sesuai dengan literature dari Nuryanti, 2010 yang membahas tentang daya saing kakao di Indonesia yang masih jauh dari perhatian pemerintah serta dinas-dinas tertentu.

\section{Kesimpulan}

\section{KESIMPULAN DAN SARAN}

1. Usahatani Bawang Merah di Kabupaten Bima memiliki keuntungan Privat sebesar Rp 21.217.584,69 per hektar dan keuntungan sosial sebesar Rp 50.686.886,84 per hektar layak untuk dikembangkan karena memiliki keuntungan kompetitif dan keuntungan komparatif

2. Komoditas Bawang Merah di Kabupaten Bima memiliki daya saing karena memiliki keunggulan kompetitif maupun komparatif. Hal ini dapat dilihat dari nilai PCR 061 dan DRCR 0,46 dimana nilai masing-masing $<1$ sehingga usahatani bawang merah ini layak untuk dikembangkan.

3. Kebijakan pemerintah pada harga input-output terhadap usahatani Bawang Merah berdampak negatif bagi penerimaan petani pada harga privat output. Berdasarkan Nilai Transfer Bersih yang negatif dan nilai NPCO yang kurang dari $<1$, namun kebijakan tersebut berdampak positif bagi petani pada harga privat input tradable berdasarkan NPCI yang diperoleh sebesar 0,94 yang berarti $<1$ memberikan arti bahwa terdapat subsidi pupuk dan obat-obatan yang membantu petani dalam mengurangi biaya input produksi.

\section{Saran}

Produkvitas bawang merah perlu ditingkatkan dengan cara memperbaiki sistem budidaya bawang merah salah satunya dengan menggunakan bibit unggul. Sehingga mutu bawang merah meningkat dan dapat bersaing di pasar internasional agar dapat meningkatkan keuntungan secara optimal. Selain itu, diharapkan kepada pemerintah dapat mempertahankan pemberian subsidi pupuk bagi usahatani bawang merah di Kabupaten Bima, menstabilkan harga jual bawang merah ditingkat petani agar petani merasa tidak dirugikan dan memberikan akses atau penyuluhan agar petani dapat mengetahui standar mutu bawang merah yang sesuai dengan permintaan pasar.

\section{DAFTAR PUSTAKA}

Asih. DN. (2009). Analisis karakteristik dan tingkat pendapatan usaha tani bawang merah di Sulawesi Tengah. Jurnal Agroland, 16(1): 53-59.

Asfih W. (2018). Aliran Kas, Pendapatan dan Struktur Pembiayaan Usahatani Bawang Merah di Kabupaten Bima. Skripsi. Fakultas Pertanian Universitas Mataram. Mataram

[BPS] Badan Pusat Statistik. (2015). Statistik Indonesia 2015. Badan Pusat Statistik: Jakarta 
Direktorat Jenderal Hortikultura. (2015). Program peningkatan produksi dan produktivitas hortikultura ramah lingkungan. Kementrian Pertanian: Jakarta.

Kementrian Pertanian. (2014). Strategi Induk Pembangunan Pertanian 2013 - 2045. Kementerian Pertanian. Jakarta Selatan.

Kementrian Perdagangan Republik Indonesia. (2015). Potensi Bawang Merah di Kabupaten Bima.

(ppp.kemendag.go.id/media_content/2017/08/Potensi_Bawang_Merah_di_Kabu paten_Bima.pdf Diakses tanggal 21 November 2018)

Ilhamsyah, (2017). Pembangunan sektor pertanian mempunyai peranan strategis dalam struktur pembangunan perekonomian nasional.

Mayrowani H \& Darwis V. (2010). Perspektif Pemasaran Bawang merah di Kabupaten Brebes, Jawa Tengah. Di dalam: suradistra $k$, Simatupang P, Hutabarat B, editor. Ptosiding Seminar Nasional Peningkatan Daya Saing Agribisnis Berorientasi Kesejahteraan Petani;2009 Okt 1; Bogor, Indonesia.

Purmiyati, S. (2002). Analisis Produksi dan Daya Saing Bawang Merah di Kabupaten Brebes Jawa Tengah [tesis]. Bogor: Institut Pertanian Bogor.

Pusat Data dan Sistem Informasi Pertanian. (2013). Statistik Harga Komuditas Pertanian Tahun 2013. Kementrian Pertanian: Jakarta.

Pusat Data dan Sistem Informasi Pertanian. (2015). Outlook Komuditas Pertanian Subsektor Horkultura. Kementrian Pertanian. Jakarta 